\author{
Victor BUSHER ${ }^{1}$ \\ Victorija YARMOLOVICH ${ }^{2}$
}

\title{
MODELING AND IDENTIFICATION OF SYSTEMS WITH FRACTIONAL ORDER INTEGRAL AND DIFFERENTIAL
}

\begin{abstract}
A universal model of fractional-order differential equation is proposed. It is derived in form hyper neuron, based on a representation of the solution of the equation by finite increments and a modified form of the Riemann-Liouville. Implemented method for identifying parameters of objects by fractional differential equations is described on the base hyper neuron and modified genetic algorithms. Accuracy of calculations is incased due to excluding of circular references and dynamic correction of the fractional integration error. This allows to use hyper neuron as inlined model of such objects in the digital control systems and in conjunction with genetic algorithm it is used for the identification of their parameters with high accuracy.
\end{abstract}

Keywords: fractional differential, fractional integral, hyper neuron, genetic algorithms, parameter identification.

\section{Introduction}

Real physical processes, that take place in nature and in the artificial technical systems and circumferences, appear to be dynamic systems, which mathematical models include differential equations of fractional order.

Thus while control of the heat transfer at delineated diffusion processes, convection it is rational to describe controlled object and regulators by fractional-order differential equations with order 0.5 . In case the condensable or bubbling up Freon serves as heat (of cold) source, the drops of liquid and gas bubbles convert heat exchange ambient into the structure similar to fractal. In such structure the effects of abnormal sub- and super-diffusion [6], while it's describing the order of the differential equations differs from 0.5 in the general case. Unsteady-state diffusion takes place in the electro chemical capacitors (ECC),

\footnotetext{
${ }^{1}$ Author to correspondence: Victor Busher, Department EMSKU Odessa National Polytechnic University, Shevchenko Avenue, Odessa 65044, e-mail: victor.v.bousher@ gmail.com

${ }^{2}$ Victorija Yarmolovich, Department TOOE Odessa National Polytechnic University
} 
that gain acceptance at present time due to the ability of rapid charge and discharge at the kinetic energy recovery system of the electric cars (KERS), due to the electrodes void structure, the current strength depends on fractional derivative of the potential [7].

As a result, energy storage and energy output in the ECC, as in accumulators, is described by a combination of the integral and fractional integral equations [8]. For the described object class the usage of the traditional methods of research may end in significant errors while parameters identification and may lead to the mismatch of the dynamic and static indexes of the systems to the estimated indexes and as a consequence to the errors while synthesis of the controlling systems [8].

\section{Study Materials}

Work objective - elaboration of the universal model of fractional differential equation random order whether for the solution of equation by method of finite increments or for the analysis and identification of the parameters of the similar systems with application of the genetic algorithms and the models of such objects realization at the discrete-controlling systems.

The fractional integration is a special case of the fractional differential equation of the following form:

$$
\ldots a_{2} D^{2+\mu} y+b_{2} \frac{d^{2} y}{d t^{2}}+a_{1} D^{1+\mu} y+b_{1} \frac{d y}{d t}+a_{0} D^{\mu} y+b_{0} y=k x,
$$

where $D^{\mu} y$-fractional derivative $y$ of the order $\mu$.

So far as

$$
\frac{d^{2} y}{d t^{2}}=\frac{d}{d t}\left(\frac{d y}{d t}\right), \quad D^{1+\mu} y=\frac{d}{d t}\left(D^{\mu} y\right), \quad D^{2+\mu} y=\frac{d^{2}}{d t^{2}}\left(D^{\mu} y\right)=\frac{d}{d t}\left(D^{1+\mu} y\right),
$$

then, get over to the finite increments, for example, for the degree of order $2+\mu$ we will deduce "fractional difference equation":

$$
D_{i}^{\mu} y=K x_{i}-A_{2} D_{i-2}^{\mu} y-B_{2} y_{i-2}+A_{1} D_{i-1}^{\mu} y+B_{1} y_{i-1}-B_{0} y_{i}
$$

Where

$$
\begin{aligned}
& A_{1}=\frac{2 a_{2}+a_{1} \Delta t}{a_{2}+a_{1} \Delta t+a_{0} \Delta t^{2}} ; A_{2}=\frac{a_{2}}{a_{2}+a_{1} \Delta t+a_{0} \Delta t^{2}} ; \\
& B_{0}=\frac{b_{2}+b_{1} \Delta t+b_{0} \Delta t^{2}}{a_{2}+a_{1} \Delta t+a_{0} \Delta t^{2}} ; B_{1}=\frac{2 b_{2}+b_{1} \Delta t}{a_{2}+a_{1} \Delta t+a_{0} \Delta t^{2}} ; B_{2}=\frac{b_{2}}{a_{2}+a_{1} \Delta t+a_{0} \Delta t^{2}} ; \\
& K=\frac{k \Delta t^{2}}{a_{2}+a_{1} \Delta t+a_{0} \Delta t^{2}} .
\end{aligned}
$$


Target value of the output coordinate $y_{i}$ can be found by method of fractional integration of the determinate value of the fractional derivative $y_{i}=I^{\mu}\left(D_{i}^{\mu} y\right)$. In the digital form the equation (2) can be assumed by schematic diagram shown at the figure 1 .

It is obviously, that changing the quantity of the return couplings and recalculating the coefficients $A_{n}, B_{n}$, it is possible to solve equations of the degree order $n+\mu$.

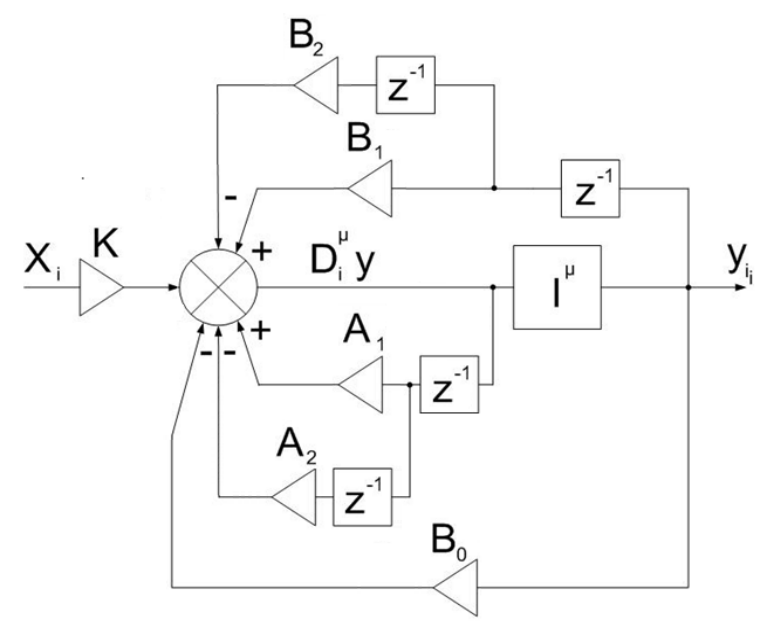

Fig. 1. Schematic diagram of the hyper neuron

Let us denote such ensemble of the components hyper neuron, the characteristics of what are close to the characteristics of the biological neurons as per the modern ideas [1]. However, while evaluation solution to the equation (2) on the $i$-step the problem occurs, connected to the null value of the output coordinate $y_{i}$ for the calculation $D_{i}^{\mu} y$ in the right side.

Let us write over (2) in the following mode:

$$
\left\{\begin{array}{l}
D_{i}^{\mu} y^{\prime}=K x_{i}-A_{2} D_{i-2}^{\mu} y-B_{2} y_{i-2}+A_{1} D_{i-1}^{\mu} y+B_{1} y_{i-1}, \\
D_{i}^{\mu} y=D_{i}^{\mu} y^{\prime}-B_{0} y_{i} .
\end{array}\right.
$$

Let us use for the solution search approximating function that is based on the modified digital form of the Riemann-Liouville [2]:

$$
y_{i}=I^{\mu}\left(D_{i}^{\mu} y\right) \approx \sum_{j=1}^{i} k_{i-j+1}^{\mu} D_{j}^{\mu} y,
$$


where $k_{n}^{\mu}=\frac{\Delta t^{\mu}}{\Gamma(1+\mu)}\left(n^{\mu}-(n-1)^{\mu}\right)$.

Then

$$
y_{i}=\sum_{j=1}^{i-1} k_{i-j+1}^{\mu} D_{j}^{\mu} y+k_{1}\left(D_{i}^{\mu} y^{\prime}-B_{0} y_{i}\right) .
$$

After generations we will receive formula for the revised figuring $y_{i}$ :

$$
y_{i}=\frac{\sum_{j=1}^{i-1} k_{i-j+1}^{\mu} D_{j}^{\mu} y+k_{1} D_{i}^{\mu} y^{\prime}}{1+k_{1} B_{0}} .
$$

Resulting expression statement (3), (6) afford exclude circular reference while figuring signal output of the hyper neuron.

Proposed method is characterized by the first order accuracy relative to the step $\Delta t$, but absolute accuracy for the arbitrary signals is at $20 \ldots 50$ times less, then using initial form Riemann-Liouville.

The objects prescribed by the fractional differential equations are the various technological processes or devices during operation of what the convection and diffusion effects appear.

Normally it is sufficient to describe such effects in the equations of the or$\operatorname{der} \mu=0.5$. However, in recent years the devices with porous laminated surface appeared and films with diverse pattern and characteristics of the micro pore at the varied depth appeared; especially while the diffusion of the charged particles.

Order of the equations govern the study of such structures behavior is determined by the extensional or surface dimension of the fractals and not only differs from 0,5 but also changes in transient process.

For the reckoning of the equation solution with the variable $\mu$ let us accept , that for $j$ instant of time the equation order is characterized by any $\mu_{j}$, and we will receive the following formulas from the (4) and (6):

For the reckoning of the fractional integral $x(t)$ :

$$
y_{i}=\sum_{j=1}^{i} k_{i-j+1}^{\mu_{j}} x_{j},
$$


Or for the reckoning of the solution for fractional differential equation:

$$
y_{i}=\frac{\sum_{j=1}^{i-1} k_{i-j+1}^{\mu_{j}} D_{j}^{\mu} y+k_{1}^{\mu_{i}} D_{i}^{\mu} y^{\prime}}{1+k_{1}^{\mu_{i}} B_{0}} .
$$

The certainty of such solution is unknown, as the theoretical basis of the fractional integrating with time-varying order $I^{\mu(t)} f(t)$ is not formulated, however, when considering wander of the parameter $\mu(t)$ such attitude to the reckoning is assumed logical. But it is necessary to try to estimate the accuracy of such reckoning.

Solution check can be founded on the following property of the fractional:

$$
I^{\mu_{1}}\left(I^{\mu_{2}}(x)\right)=I^{\mu_{1}+\mu_{2}}(x) .
$$

Taking $\mu_{2}=1-\mu_{1}$, we will deduce

$$
I^{\mu}\left(I^{1-\mu}(x(t))\right)=\int_{0}^{t} x(t) d t .
$$

As the evaluation of the first-order integral for the analogue functions is admissible with high accuracy, thus the measure of inaccuracy $\delta(t)$ can be evaluated for the consequent analysis of the fractional integrals (fig.2).

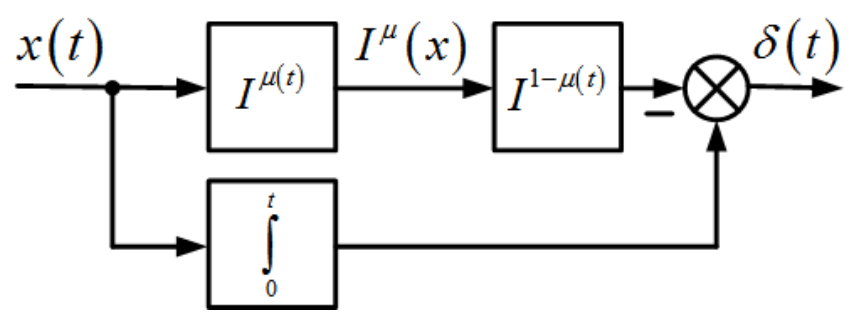

Fig. 2. Determination of the of the fractional integral calculation error

Deduced value of error $\delta(t)$ for the every instant can be used for the dynamic correction of the reckoning of the fractional integrals by the method of correcting input signaling.

However the error arises in result of double fractional integration, i.e. each from two components inserts its part of error. For the correctional signal rearrangement we will use the fact, that when integrating the identical signals with 
the fractional integrating continued order of the calculating error in case of different $\mu$ vary, but in case of $\mu$ and $1-\mu$ they coincide (fig.3).

It follows that, the inaccuracy can be reallocated with weight coefficient 0,5 .

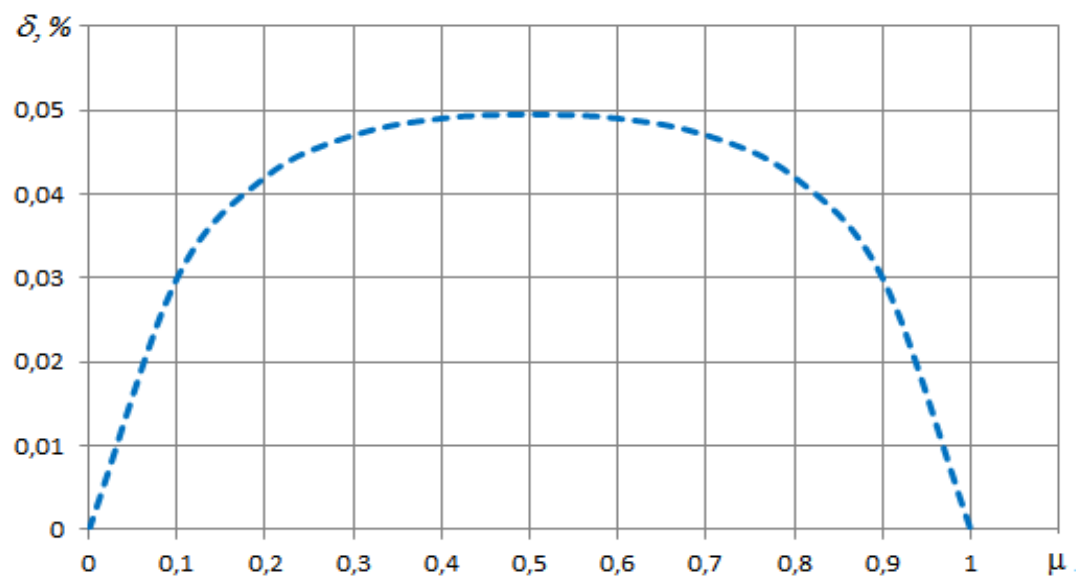

Fig. 3. Calculation error of the fractional integral with $\mu=$ const

As the correcting signal will be integrated, thus for it's origination let us differentil $\delta(t)$.

Let us give a signal to the input of the first fractional integrating element. For the check of the results obtained let us calculate fractional derivative of the inaccuracy with order $1-\mu$, using the correspondence between the derivative and integral $D^{1-\mu}(\delta)=\frac{d}{d t}\left(I^{\mu}(\delta)\right)$, and we will give it to the input of the second fractional integrating element.

Resulting arithmetic model of the calculating block for the fractional integral with assumed dynamic correction is provided at the figure 4. Corrected value of the fractional integral $I_{v}^{\mu}(x)$ forms output signal of the block. Circuit «Test» allows comparing calculation errors without $\delta$ correction and after $\delta$ correction but it`s not necessary when calculating the fractional integral.

With constant order of the fractional integrating the supposed dynamic correction cures totally the inaccuracy in case of arbitrary input (fig. 5).

On the figure 6, a is shown fractional integral calculation example in case of integration order wander, figure $6, \mathrm{~b}$ shows that when counting the dynamic correction the computational error is reduced more than in twenty times. 


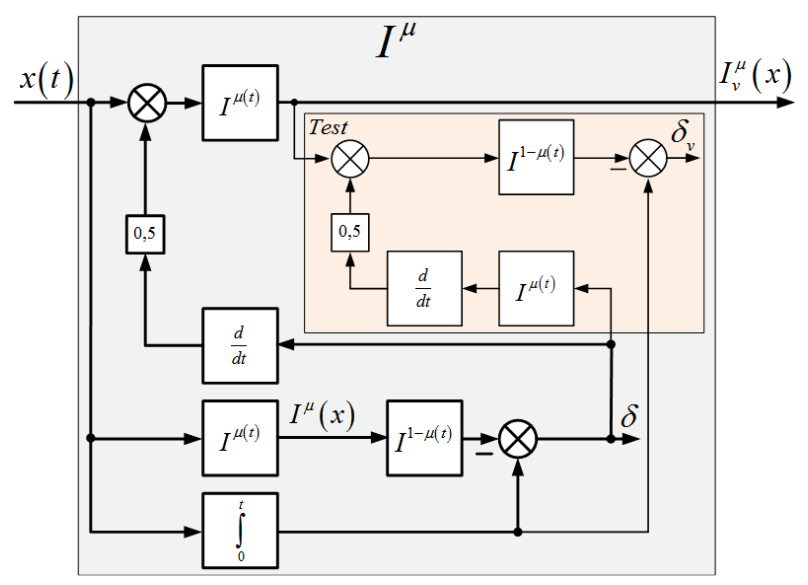

Fig. 4. Arithmetic model of the settlement block for the fractional integral with dynamic correction of inaccuracy

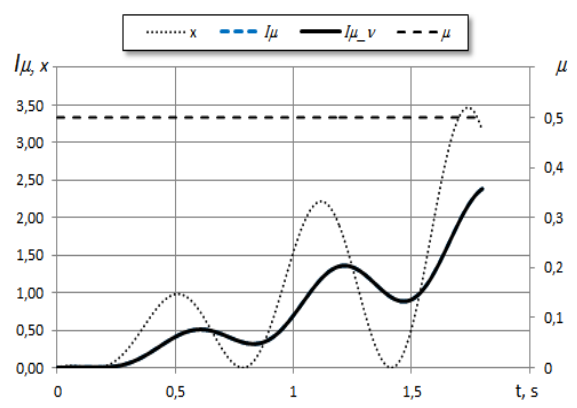

a)

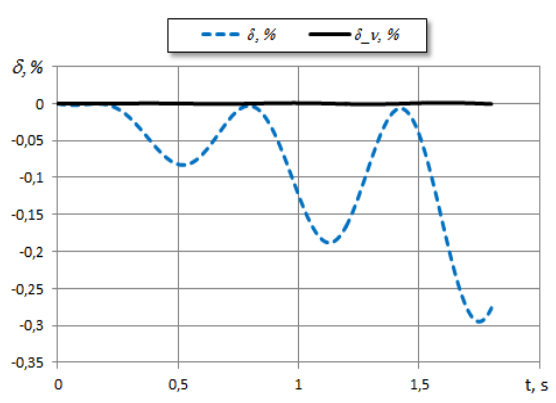

b)

Fig. 5. Graphs of fractional integral variance (a) and error modify (b) with and without dynamic correction in case $\mu=$ const

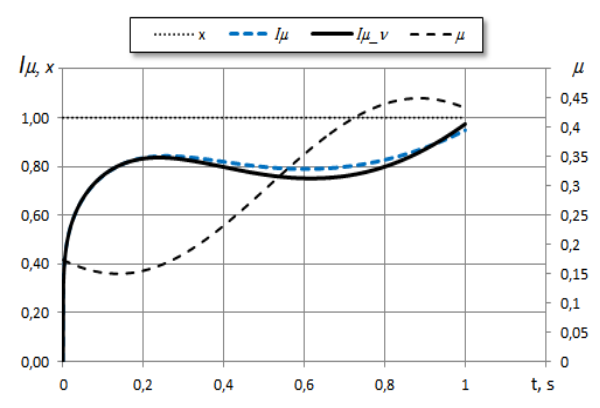

a)

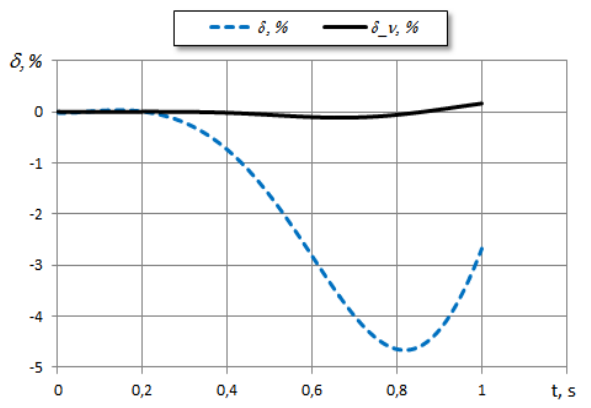

b)

Fig. 6. Graphs of fractional integral variance (a) and error variance (b) with and without dynamic correction in case $\mu=$ var 
Besides, with rapid change of the $\mu$ solution without correction is characterized by the inaccuracy increasing through the amplitude, i.e. the unit can become structural-unstable. Dynamic correction enhances accuracy and stability of calculation significantly (fig. 7).

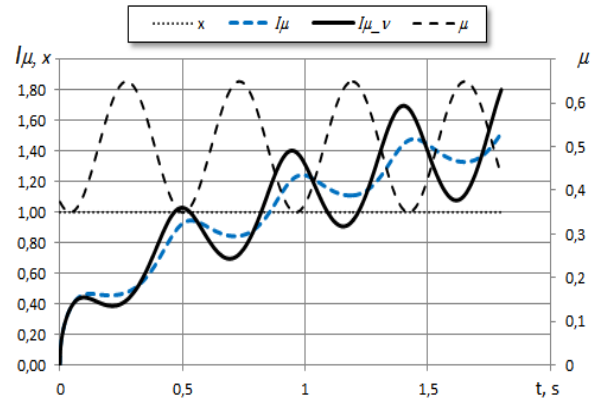

a)

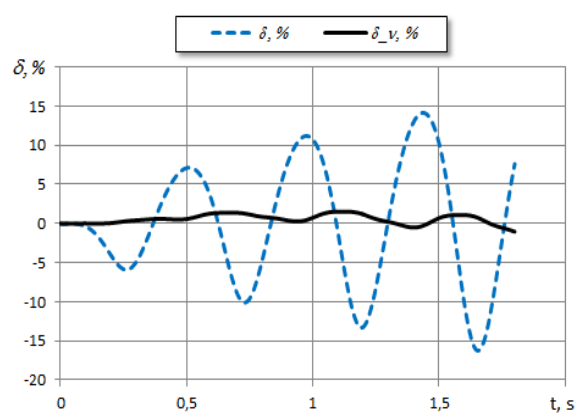

b)

Fig.7. Graphs of variance in fractional integral (a) and error variance (b) in case of «Bhighfrequency» vibrations $\mu$

Hence estimated germ is deduced for the reckoning of the solutions for the fractional differential equations with time-variant order inter alios.

If transient functions received in the result of the research tests, thus genetic algorithms [3] can be used for identification of the objects parameters admissibly governed by the fractional differential equations (1),

From all their variety method of multipoint crossing $40 \%$ optimum specimen with insertion of $6 \%$ discarded specimen in following manner. Multipoint crossing chooses the germ of the genetic algorithm, that is implemented by the random variations of the instance characteristics $\pm 5 \%$ [1], for the population degeneration exclusion.

Deduced two derivatives substitute $40 \%$ of the discarded specimen. Another more $20 \%$ of the derivatives are deduced as averaging from the genes of the procreators, and one of the best specimen descendants deduced in the ancestor is the specimen, which parameters are determined by the gradient of the best specimen parameters modifications for the last several descents.

Figure 8 illustrates the results of the object identification, declared by the fractional differential equation with indexes $a_{0}=0,35 ; a_{1}=0,175 ; b_{1}=2 ; b_{2}=0,006 ; \mu=0,5$. Indexes of the identified object $a_{0}=0,39 ; a_{1}=0,173 ; b_{1}=7,5 ; b_{2}=0,006 ; \mu=0,53$ force error retrieving $0,64 \%$, mode of the transient order aligns with stated, that allows to use identified indexes for the further analysis and synthesis of the control systems. 
Figure 9 illustrates the training processes - changing of values $\mu$ and mean-squared error of the output signal of the best specimen is shown relative to the original signal $F_{b e s t}$ from the generation number Gen.

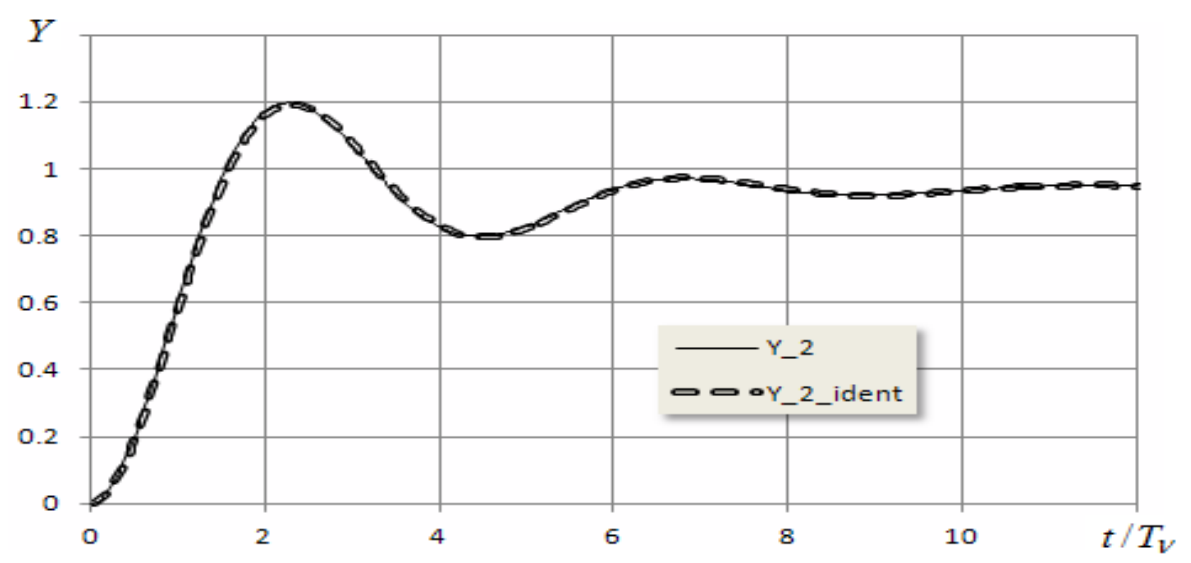

Fig. 8. Schedule of the transition processes for the initial and identified objects

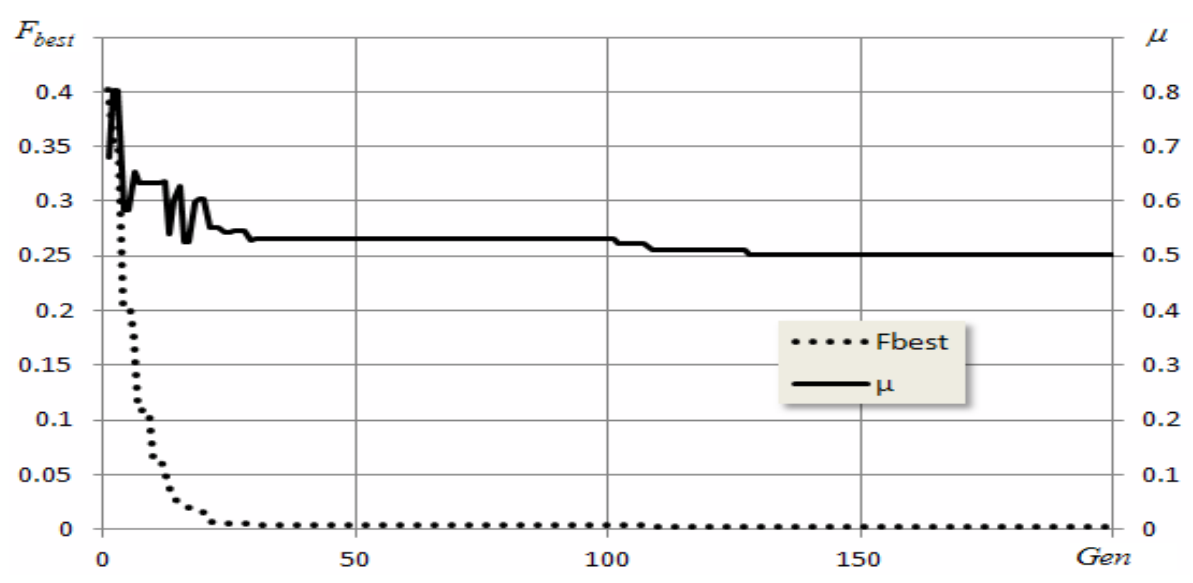

Fig. 9. Schedule of variance $\mu$ and $F_{\text {best }}$ in the training process

Developed methods of calculation and identification are used for the parameters identification for the ECC, which arithmetical model includes seriesconnected integrator, proportional and fractional integrating component with two groups of the parameters (for ECC charge and discharge): $C_{+}, C_{-}-$ECC capacitance, $R_{+}, R_{-}$- direct-current resistance, $B_{+}, B_{-}, \mu_{+}, \mu_{-}-$diffusion coefficient and the integration order, describing diffusional and adsorptive features 
of the double electrical layer. Differential equation in the operator form, explaining the voltage change on the ECC connecting devices $U$ in the process of charge/discharge by the current $I$ with interval $t_{c h}$, should be set down on the following mode:

$$
\begin{aligned}
& U(p)=\left(R+\frac{1}{C p}+\frac{1}{B p^{\mu}}\right) I(p), \\
& \mu(t)=\mu\left(A_{\mu} \cos \left(\pi \frac{t}{t_{c h}}+\varphi\right)+1\right) / 2,
\end{aligned}
$$

Where $A_{\mu} \in[0,1], \varphi \in[-\pi,+\pi]$ - additional parameters.

Such law of variation $\mu$ with direct current of the charge/discharge corresponds also to the dependency $\mu$ from the ECC voltage.

Fractional integral component as per it's features in the proposed model appears transitory between integral and proportional elements: it looks like an integral element in the transient processes and in the steady-state processes it looks like proportional element. Particularly, when the rectangular pulse is supplied to the lead terminal, output signal increases but not rectilinear, but in an exponential function and when the input signal is dropped till 0 , the output signal drops to zero under the same law, instead of being stable. Such features are verified in the feed rates of the current step to the super condenser and when it's voltage is stabilized.

But in the steady state mode behavior of ECC is equivalent to the behavior of the standard condenser. Thus, if we supply a current step of the definite value to ECC and then over time, supporting a constant voltage, will reset the current to zero ( fig. 10, a), then step voltage at the initial time will be proportional to the internal resistance of ECC and the ratio between current integral and voltage change will be proportional to it's capacitance. Diffusion effects don't influence on the results of such metrics.

That is why testing and experimental data processing for the ECC parameters definition consist of several steps.

1. The test series of the current impulses of diverse pulse height for ECC charge and discharge is supplied on ECC with further voltage stabilization until the current becomes close to zero (fig. 10, b) and current and voltage measurements should be carried out with constant pitch $\Delta t$ (units, ten milliseconds). The test series consists of the condenser charges/discharge cycles of the currents from 20 to $100 \mathrm{~A}$, repeating several times for the further averaging results. 


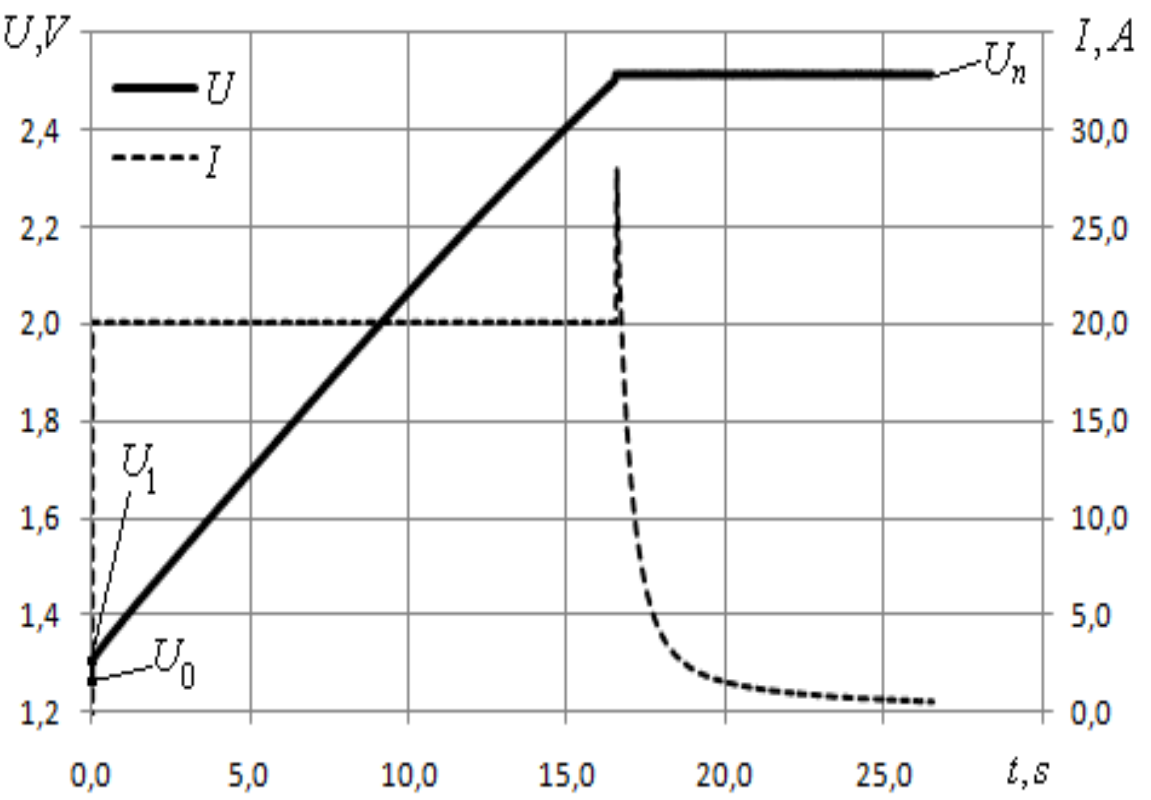

a)

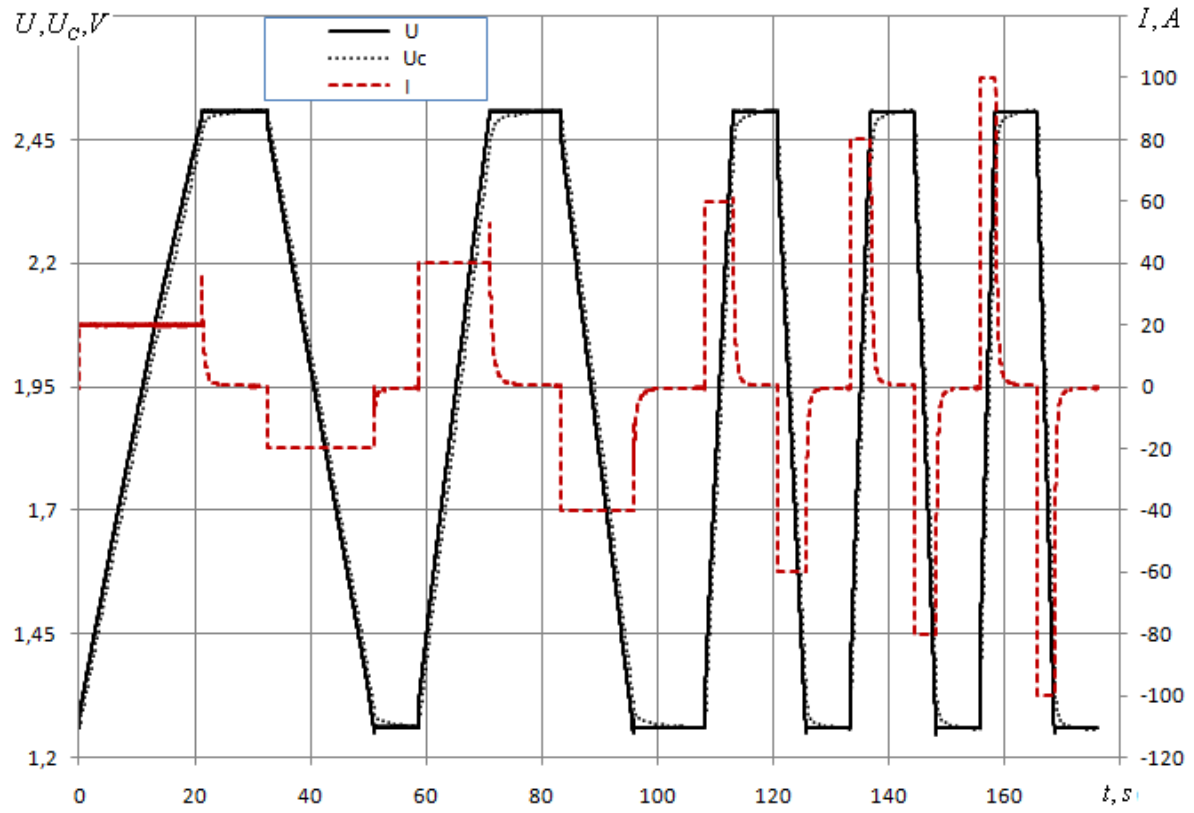

b)

Fig. 10. ECC charge (a) in the cycles series of charge/discharge (b) 
2. Based on current integral and voltage change ECC capacitance is determined :

$$
C=\frac{\int_{0}^{t} I(t) d t}{\Delta U} \approx \frac{\sum_{i=1}^{n} I_{i} \Delta t}{U_{n}-U_{1}}
$$

3. As actually the current step intervenes for the $k=1 . . .2$ intervals, thus after capacitance index calculation resistance value should be determined:

$$
R=\frac{U_{k}-U_{0}-\sum_{i=1}^{k} \frac{I_{i} \Delta t}{C}}{I_{k}-I_{0}},
$$

Parameters obtained allow to distinguish separate voltage components in the ECC: voltage drop on the active resistance, charging voltage of the capacitance and voltage loss in the diffusion layer. The graphs of the voltage change in ECC diffused layer are shown on the figure 11, demonstrating changing order of the fractional integration. Processing of the last compound allows to determine constraint $\mu$ from the voltage and charge/discharge current, presented on the figure 12 for ECC with capacitance index $1800 \mathrm{~F}$.

Except that in the process of the ECC identification with capacitance up to $300 \ldots 400 F$ when this feature can be ignored. Voltage loss in the diffusion layer is close to the voltage loss on the active resistance. Standard error while describing the experimental data, does not exceed $0.0045 \mathrm{~V}\left(0.2 \% \mathrm{U}_{\max }\right)$ for ECC with nominal voltage $2.5 \mathrm{~V}$.

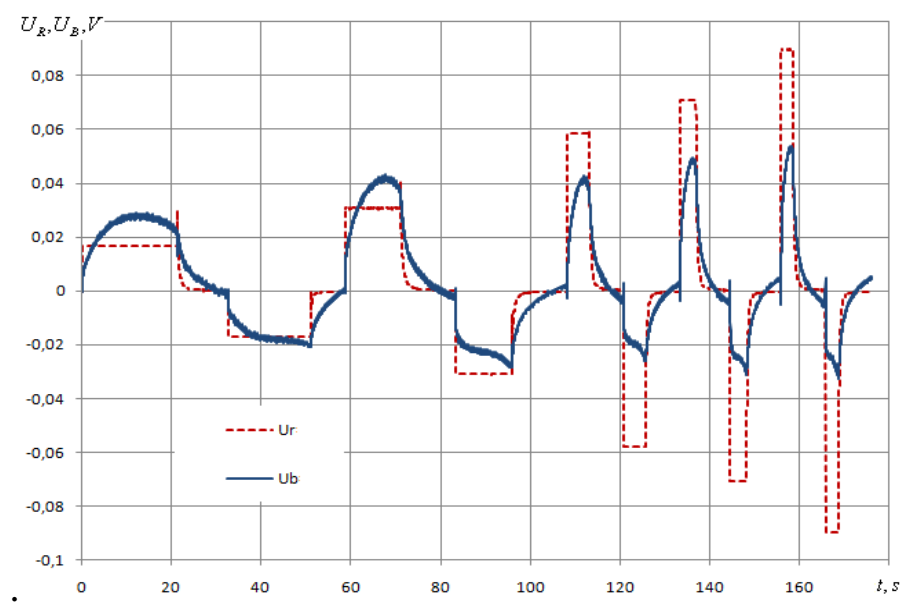

Fig. 11. Graphic charts of the voltage loss in the diffusion layer 


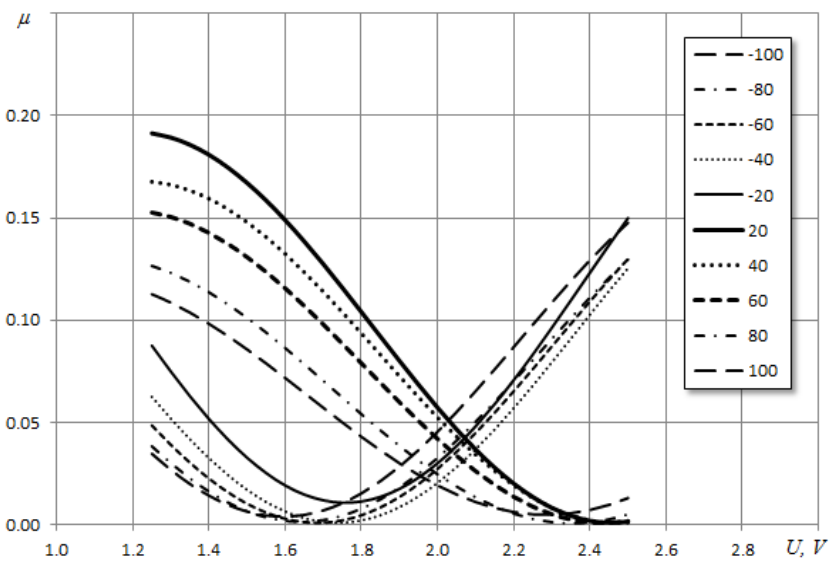

Fig. 12. Dependency graphs $\mu=f(U, I)$

But when identifying ECC diffusion parameters of the high capacity $(>1000 \mathrm{~F})$ this feature should be taken into consideration, as the voltage loss in the diffusion layer exceeds voltage loss on the active resistance in $2 . . .3$ times.

As the result such correction allows describe ECC behavior not only with inaccuracy no less than $0,05 \ldots 0,1 \% U_{\max }$, but also allows us to obtain the graphs diagrams of the transient processes, that are equivalent by their behavior to the experiment on the whole interval of the charging and discharge ECC current (fig. 13).

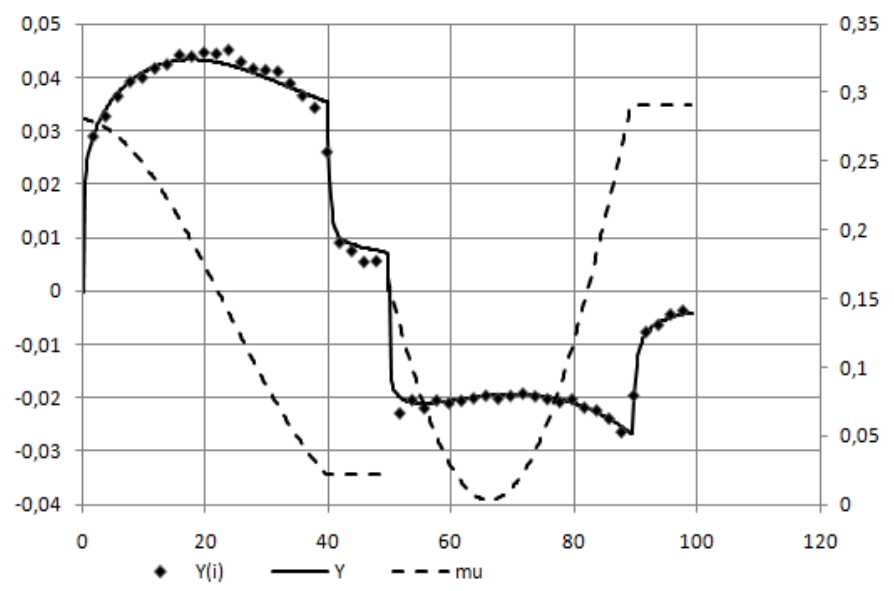

Fig. 13. Experiment graph diagram $\left(U_{i}\right)$ and nomogram charts $(U)$ of voltage loss in the diffusion layer of the ECC with capacitance $1800 \mathrm{~F}$ considering changes of $\mu$ (dashed line) 


\section{Conclusion.}

In order to describe the behavior of the objects consisting of models of the fractional differential equations of random order, including the order variable in the transition process, the model of hyper neuron has been formulated, based on the method of finite increments application and modified discrete form of Riemann-Liouville. Accuracy of calculations is incased due to excluding of circular references and dynamic correction of the fractional integration error. This allows to use hyper neuron as inlined model of such objects in the digital control systems and in conjunction with genetic algorithm it is used for the identification of their parameters with high accuracy.

\section{References}

[1] Rutkowska D., Pilinski M., Rutkowski L. Sieci neuronowe, algorytmy genetyczne i systemy rozmyte, (1999), Naukowe PWN, Warszawa, pp. 452 (In Polish).

[2] Busher V. V. The model of system with fractional integral and fractional differential in SIMULINK, (2011), Elektromekhanichni i enerhozberihayuchi systemy Publ., Kremenchuk, Vol. 4/2011, pp.138-142 (In Russian). http://archive.mdct.ru/portal/natural/Ees/2011_4/140.pdf

[3] Busher V. V. Evolution algorithms as method of identification of climate control system objects described by fractional equations, (2010), Electrotechnic and computing systems, Technica Publ., Kyev No02(78), pp.68-72 (In Russian). archive.nbuv.gov.ua/portal/natural/emeo/2011_78/068-072.pdf

[4] Busher V. V. Identification of the elements of climate systems of differential equations of fractional order, (2010), Elektromashynobud. ta elektroobladn., Technica Publ., Kyev, Vol. 75, pp.68-70 (In Russian). archive.nbuv.gov.ua/portal/ natural/emeo/2010_75/068-070.pdf

[5] Uchaikin V. V. Fractional differential model of dynamic memory, (2001), Matematyka y mekhanyka Publ., pp.14 (In Russian).

[6] Uchaikin V. V. Anomalous Diffusion and Fractional Stable Distributions ,(2003), Journal of Experimental and Theoretical Physics Publ., No. 4, pp.810-825 (In English).

[7] Hyl'mutdynov A., Ushakov P., Hyl'metdynov M. Fractional operators: synthesis and implementation criteria, (2008), Nelyneynuy myr Publ., No. 8, pp.452-463 (In Russian).

[8] Busher, V. V. Martynyuk V. V., Naydenko E. V. Energy indicators and parameters ultracapacitors in dynamic modes, (2012), Vymiryuval'na ta obchyslyuval'na tekhnika v tekhnolohichnykh protsesakh Publ., Khmel'nyts'kyy, . No. 1, pp.44-50 (In Russian). archive.nbuv.gov.ua/portal/Natural/Vtot/2012_1/31bus.pdf

[9] Busher V. V. Synthesis of process control systems with integrated fractionaldifferentiating properties, (2012), Vostochno-Evropeiskii Zhurnal Peredovykh Tekhnologii. Energosberegayushchie Tekhnologii i Oborudovanie Publ., Kharkov, Ukraine, Vol.4/3 (58), pp. 32-37 (In Russian). ar-

chive.nbuv.gov.ua/portal/natural/Vejpt/ 2012_4_3/...4.../32_37.pdf 


\section{MODELOWANIE I IDENTYFIKACJA PARAMETRÓW SYSTEMÓW Z ELEMENTAMI CAŁKOWO-RÓŻNICZKOWYMI UŁAMKOWEGO RZĘDU}

\section{Streszczenie}

Zaproponowano uniwersalny model różniczkowego równania ułamkowego rzędu w postaci hyper neuronów, podstawową którego jest stosowanie metody przyrostów skończonych i modyfikowanej formy Riemann- Liouville do przedstawienia rozwiązania równania. Korzystając z hyper neuronów i modyfikowanych algorytmów genetycznych zrealizowana została metoda identyfikacji parametrów obiektu opisywanego ułamkowymi całkowo-różniczkowymi równaniami. Zaproponowana metoda dynamicznej korekcji obliczenia stanów nieustalonych, dla systemów ze zmiennym rzędem ułamkowego całkowania, zapewnia wyższą wiarygodność wyników. Opracowana metoda pozwala na modelowanie procesów w elektrochemicznych kondensatorach dużej pojemności z wysoką dokładnością.

Słowa kluczowe: różniczkowanie ułamkowe, całkowanie ułamkowe, hyper neuron, algorytmy genetyczne, identyfikacja parametrów

DOI: $10.7862 /$ re.2015.29

Tekst ztożono $w$ redakcji: maj 2015

Przyjęto do druku: wrzesień 2015 

